\title{
Experiências de formação política e intelectual de um comunista: família, etnia, leituras e militância estudantil de Jacob Gorender, um jovem membro do PCB em Salvador $(1923-1943)^{*}$
}

Carlos Fernando de Quadros**

Resumo: Jacob Gorender, destacado militante comunista e teórico marxista, é conhecido especialmente pela sua produção historiográfica a partir da década de 1970, bem como pelo seu papel nos círculos dirigentes do PCB e do PCBR entre o final dos anos 1950 e a década seguinte. Neste artigo é abordado um período menos conhecido de sua trajetória: a sua formação política e intelectual, em Salvador, nas décadas de 1920 a 1940, compreendendo a sua situação enquanto filho de uma família da classe trabalhadora, também parte da comunidade judaica local, em um período de agitações sociais. Atenta-se às suas leituras materialistas realizadas na adolescência, assim como os textos marxistas com que se deparou quando militante estudantil do PCB na Faculdade de Direito. Também são discutidas as particularidades da trajetória do PCB em Salvador no período, bem como os limites e possibilidades postos a Jacob Gorender em sua formação marxista no local e contexto em tela.

Palavras-chave: Jacob Gorender; biografia; Partido Comunista do Brasil (PCB).

Abstract: Jacob Gorender, communist militant and Marxist theorist, is known specially by his historiographical production starting from the 1970's, as well as his role in the PCB and PCBR's ruling circles between the last 1950's and the 1960's. On this paper is studied a less known period in Gorender's trajectory: his political and intellectual making of, between the 1920's and the 1940's Salvador, seeing his

* A pesquisa de mestrado de que este artigo é resultado foi financiada, entre outubro de 2014 e janeiro de 2016, pela Coordenação de Aperfeiçoamento de Pessoal de Nível Superior (CAPES).

** Doutorando em História Econômica pela Universidade de São Paulo (USP), é Mestre em História Social pela mesma instituição. Licenciado em História pela Universidade Federal do Rio Grande do Sul (UFRGS). E-mail: carlosfquadros@gmail.com. 
situations as a member of a working class family, as well as a member of the local jewish community, in a social tribulation time. Is an object of attention Gorender's materialistic readings when he was a teenager, as well as the Marxist texts that he contacted as a student activist of the Communist Party in Law School. The particularities in PCB's trajectory in Salvador are discussed too, even as the limits and possibilities that Jacob Gorender faced in his Marxist making of in the period and site in study.

Keywords: Jacob Gorender; biography; Brazilian Communist Party (PCB).

As biografias de militantes comunistas estão em evidência no Brasil. Um indício é o celebrado Prêmio Jabuti, no qual dois vencedores na categoria biografia nos últimos quatro anos concorriam assinando obras centradas em destacados quadros brasileiros: Luiz Carlos Prestes, dirigente máximo por quase quatro décadas do Partido Comunista do Brasil, transformado em Partido Comunista Brasileiro (PCB), e Carlos Marighella, membro importante do PCB, de ação notável na luta armada posterior a 1964, dirigindo a Ação Libertadora Nacional (ALN), organização destacada nos ditos "anos de chumbo". A referência é feita aos livros Marighella: o guerrilheiro que incendiou o mundo, ${ }^{1}$ do jornalista Mário Magalhães, e Luís Carlos Prestes. Um revolucionário entre dois mundos, ${ }^{2}$ texto publicado pelo veterano historiador Daniel Aarão Reis. Não foram as únicas publicações de destaque no que tange a trajetórias individuais no seio do movimento comunista no Brasil. $\mathrm{O}$ citado Prestes foi objeto de outro livro, ${ }^{3}$ escrito pela sua filha, a historiadora Anita Leocádia Prestes, vindo a lume em 2015, menos de um ano depois do lançamento da biografia escrita por Aarão Reis. O historiador marxista Caio Prado Júnior vem sendo visitado pela historiografia e ciências sociais no Brasil com grande frequência, sendo três as biografias suas publicadas nos últimos nove anos. ${ }^{4}$

Outros comunistas brasileiros, com menor destaque do que os citados, também foram objetos de biografias. Tal é o caso, por exemplo, de Mário Alves, que chegou a tomar parte no Comitê Central do PCB e foi dirigente do Partido Comunista Brasileiro Revolucionário (PCBR) até a sua morte, nas mãos de torturadores, em 1970. A sua vida foi narrada por Gustavo Falcón, que transformou a sua tese de doutorado em livro, sob o título Do reformismo à luta armada. A trajetória política de Mário Alves (1923-1970). 5 Joaquim da Câmara Ferreira, conhecido por intervenções e cumprimento de função dirigente na imprensa comunista, bem como pelos tempos de guerrilha pela ALN, também foi biografado em $O$ revolucionário da convicção. Vida e ação de Joaquim da Câmara Ferreira. ${ }^{6}$

Esses casos compreendem apenas alguns exemplos de uma produção variada que vem crescendo nos últimos anos. Percebe-se, portanto, um quadro de crescimento na publicação de textos abordando trajetórias de militantes comunistas,

1 MAGALHÃES, Mário. Marighella. O guerrilheiro que incendiou o mundo. São Paulo: Companhia das Letras, 2012.

2 AARÃO REIS, Daniel. Luís Carlos Prestes. Um revolucionário entre dois mundos. São Paulo: Companhia das Letras, 2014.

3 PRESTES, Anita. Luiz Carlos Prestes. Um comunista brasileiro. São Paulo: Boitempo Editorial, 2015.

4 IUMATTI, Paulo. Caio Prado Junior. Uma trajetória intelectual. São Paulo: Editora Brasiliense, 2007; SECCO, Lincoln. Caio Prado Júnior. O sentido da revolução. São Paulo: Boitempo Editorial, 2008; PERICÁS, Luiz Bernardo. Caio Prado Júnior. Uma biografia política. São Paulo: Boitempo Editorial, 2016.

5 FALCÓN, Gustavo. Do reformismo à luta armada. A trajetória política de Mário Alves (1923-1970). Salvador: Versal Editores; Editora UFBA, 2008.

6 CASTRO SILVA, Luiz Henrique. O revolucionário da convicção. Vida e ação de Joaquim Câmara Ferreira. Rio de Janeiro: Editora UFRJ, 2010. 
porém cabe lembrar que as biografias não constituem novidade no que tange à história e historiografia do movimento operário.7

Benito Schmidt, em artigo referente ao tema, escrito nos anos $1990 \mathrm{com}$ foco na produção a partir da década anterior "[...] quando verificou-se uma profunda renovação dos estudos sobre a classe operária no nosso país", 8 já tratou de discutir textos referentes às vidas de militantes operários. À época, o autor abordou cinco biografias, constando um anarquista, dois socialistas, uma feminista e uma comunista como personagens em tela. Schmidt era atento à diferença entre esses textos, alinhados às preocupações historiográficas desenvolvidas no espaço acadêmico, com relação à produção via de regra apologética de autoria de historiadores militantes não profissionais.

Da produção acadêmica de biografias de militantes operários, é essencial o que o historiador destacou enquanto à busca de compreender, a partir de trajetórias individuais, questões mais amplas da história operária (um processo de circulação de ideias políticas, por exemplo), bem como relativizando análises pautadas seja por uma estrita determinação estrutural ou, ao contrário, pela absoluta liberdade individual, atentando assim à tensão com que sujeito e estrutura se relacionam na realidade histórica. Por fim, Schmidt também percebeu que a dimensão privada da vida dos militantes emergiu na "nova" biografia de militantes, a qual demanda, muitas vezes, certa imaginação da parte dos historiadores, a qual é balizada pelas fontes e bibliografia, ou seja, assume a forma de hipóteses controladas. ${ }^{9}$

Nesse sentido, de um renovado interesse em trajetórias de comunistas, orientado pelos pertinentes desenvolvimentos teórico-metodológicos da historiografia contemporânea presentes no gênero biográfico e elencados nos parágrafos anteriores, que é proposto este artigo. Atenta-se aqui a Jacob Gorender, destacado militante comunista e teórico marxista, conhecido pelos estudiosos da história do movimento operário e da esquerda especialmente pela sua produção historiográfica a partir da década de 1970, bem como pelo seu papel nos círculos dirigentes do PCB e do PCBR entre o final dos anos 1950 e a década seguinte. Neste texto é abordado, contudo, o período menos conhecido de sua trajetória, o de sua formação política e intelectual na Bahia das décadas de 1920 a 1940, espaço no qual seus pais se estabeleceram após sua migração do Império Russo. Em tal período, constituíram família, da qual Jacob Gorender era o primogênito. Aqui se atenta à educação de Jacob, entendido enquanto filho de uma família da classe trabalhadora, pertencente à comunidade judaica local, em um período de agitações sociais em que os trabalhadores assumiram posição protagonista, a qual é acompanhada especialmente pela constituição do Partido Comunista, uma das expressões de suas lutas e experiências. São abordadas também as suas leituras materialistas realizadas na adolescência, bem como os textos marxistas com que se deparou quando militante estudantil do PCB na Faculdade de Direito. É uma preocupação aqui destacar as particularidades no desenvolvimento do PCB na Bahia do Estado Novo (período em que a organização lá teve atuação destacada, ao contrário de outros centros nacionais) a partir das experiências da militância jovem local, onde Jacob Gorender teve papel importante. O interesse principal neste texto é também discutir as múltiplas orientações postas na formação de um marxista, procurando assim compreender as múltiplas

7 Já tem quase um século do lançamento da biografia de Karl Marx pelo histórico militante alemão Franz Mehring. Cf: MEHRING, Franz. Karl Marx - A história de sua vida. São Paulo: Editora Sundermann, 2013.

8 SCHMIDT, Benito. "Trajetórias e vivências. As biografias na historiografia do movimento operário brasileiro”. Projeto História, (16), p.236, (fev. 1998).

9 SCHMIDT. "Trajetórias e vivências", p.238-242. 
possibilidades e constrangimentos postos a Jacob Gorender em um espaço e tempo específicos, abordagem - atenta à articulação entre o político e intelectual - que pode contribuir no avanço de interpretações acerca de indivíduos, movimentos e correntes em diálogo com as experiências dos trabalhadores.

\section{Jacob Gorender, filho de trabalhadores judeus na Bahia: família, comunidade, leituras e ensino básico em período de agitação social}

As mobilizações da classe trabalhadora tiveram caráter acentuado no Brasil, como no resto do planeta, ao final da década de 1910. Tempos de guerra, protagonizada pelas principais potências imperialistas e envolvendo povos de todos os cantos do globo. Junto a tal processo, revolução na Rússia e insurreições em variadas localidades europeias. O horizonte de mudanças estruturais era uma possibilidade bastante crível aos atores sociais.

Na Bahia não foi diferente. Se 1917 é o ano vermelho, tanto na longínqua Rússia quanto em algumas grandes cidades brasileiras marcadas pela mobilização de trabalhadores anarquistas e socialistas, é apenas em 1919 que Salvador conhecerá a sua greve geral, entre os dias 2 e 12 de junho. Foi um período de dois anos que constituiu uma conjuntura de agitações operárias. ${ }^{10}$

A classe operária baiana ensaiava mais um passo em sua formação enquanto ser social de atuação política. Os trabalhadores urbanos ainda eram pequena minoria se comparados aos empregados em atividades agrícolas, mas a sua presença não era ignorável. José Fontes já enumerou as organizações de trabalhadores soteropolitanas, pregressas aos grevistas de 1919 e imediatamente posteriores, com destaque para partidos de cariz socialista e operário já em 1890, forma organizativa que, pari passu à difusão do anarquismo, retornava ao cenário baiano já a partir de 1920, o que pode ter conformado a memória dos engajados socialmente a partir de então. ${ }^{11}$

Já corria mais de uma década do momento em que o casal judeu Nathan e Anna Gorender, por caminhos distintos, abandonou sua terra natal, firmando residência em Salvador, após breve período em Buenos Aires, onde se conheceram. Ambos oriundos do Império Russo: ele, da Ucrânia, Anna, por sua vez, da Bessarábia. Nathan teve atuação militante alhures, pegando em armas junto dos revolucionários de 1905 em Odessa. A causa de sua migração foram os pogroms - a perseguição popular, com apoio do Estado, aos judeus. ${ }^{12}$

Os Gorender constituíam uma família pobre, sofriam de agruras que acometiam os subalternos. Nathan, mais um trabalhador urbano em um estado fundamentalmente agrário, integrava o coletivo de pessoas que, se não constituíam a

10 CASTELLUCCI, Aldrin. Industriais e operários baianos numa conjuntura de crise (1914-1921). Salvador: FIEB, 2004.

11 FONTES, José. "Marighella e o movimento operário baiano no período da "redemocratização" (19451947)". In: NOVA, Cristiane; NÓVOA, Jorge (orgs.). Carlos Marighella: o homem por trás do mito. São Paulo: Editora UNESP, 1999, p.292-293.

12 Algumas possibilidades referentes às experiências políticas russas de Nathan Gorender, bem como de seu período com Anna em Buenos Aires, aqui mencionados en passant, são discutidas com maior vagar em trabalho anterior de minha autoria. Cf: QUADROS, Carlos. "Jacob Gorender, um militante comunista: estudo de uma trajetória política e intelectual no marxismo brasileiro (1923-1970)". (Dissertação de mestrado em História Social, Universidade de São Paulo, 2015), p.28-35. 
maioria do setor produtivo local, já experimentavam a condição de ser uma classe social específica no modo de produção corrente. Edward Thompson, atento ao fenômeno da formação da classe operária inglesa, lançou mão de importantes definições quanto a tal processo:

\begin{abstract}
A classe acontece quando alguns homens, como resultado de experiências comuns (herdadas ou partilhadas), sentem e articulam a identidade de seus interesses entre si, e contra outros homens cujos interesses diferem (e geralmente se opõem) dos seus. A experiência de classe é determinada, em grande medida, pelas relações de produção em que os homens nasceram - ou entraram involuntariamente. A consciência de classe é a forma como essas experiências são tratadas em termos culturais: encarnadas em tradições, sistemas de valores, ideias e formas institucionais. ${ }^{13}$
\end{abstract}

Essa condição, a de uma classe social formada no processo de experiências em comum, compreendeu variadas formas de assalariamento em Salvador, sendo a de maior relevância política então a dos trabalhadores fabris. A articulação de interesses assemelhados expressou-se na greve geral de 1919, bem como em outras ocorrências de luta. Não é demasiado cogitar que os trabalhadores não fabris, caso de Nathan Gorender, que era entregador de pães, também tenham se animado naqueles "tempos de aguda perturbação social”, para recuperar novamente uma expressão de Thompson. Ressalte-se que Nathan já carregava experiências de luta desde o solo russo.

A mobilização operária, em um processo nacional, resultou, entre outras coisas, na formação do Partido Comunista do Brasil, Seção Brasileira da Internacional Comunista (SBIC), em março de 1922, quando nove delegados, representando 73 militantes, oriundos de variadas localidades nacionais reúnem-se em Niterói para um congresso objetivando a "[...] fundação de um Partido Comunista, de acordo com as 21 condições fixadas pela III Internacional para reconhecimento dos partidos comunistas como sua seção nacional". ${ }^{14}$

As ideias e a prática marxista aportaram a partir de então de fato no Brasil, iluminadas pela influência da Revolução de Outubro e difundidas pelo PCB, que reivindica o seu legado. O caminho é diverso do percorrido por países, tanto da Europa Ocidental quanto vizinhos latino-americanos, que experimentaram, antes de 1917, um período de predominância de organizações social-democratas ou socialistas, unidas sob o signo da II Internacional. ${ }^{15}$ Já em 1924, na égide do marxismo inspirado pela Internacional Comunista (IC), que surge a primeira tentativa de interpretação marxista da realidade brasileira, quando, sob o pseudônimo de Fritz Mayer, Octávio Brandão, publica Agrarismo e industrialismo no Brasil: ensaio marxista-leninista sobre a revolta de São Paulo e a guerra de classes no Brasil. O autor discute a articulação entre a dominação imperialista no Brasil e a presença do problema do "agrarismo", expresso na aliança entre "oligarquia agrária entrelaçada com a oligarquia financeira". A tese adquire grande relevância dentre as formulações e projetos políticos do PCB, ensejando uma aliança entre a classe operária e a pequena burguesia democrática rebelde ${ }^{16}$. ro: Paz e Terra, 1987, p.10.

14 RODRIGUES, Leôncio Martins. "O PCB: os dirigentes e a organização". IN: FAUSTO, Bóris (org.). História Geral da Civilização Brasileira: Tomo III, Vol. 10, O Brasil Republicano. São Paulo: Difel, 1981, p.363.

15 Cf: SECCO, Lincoln. "Origens intelectuais do marxismo no Brasil (1830-1919)". Mouro, Revista Marxista Núcleo de Estudos d'O Capital. Ano 4, n.6, p.9-24, janeiro de 2012.

16 QUARTIM DE MORAES, João. "Octávio Brandão". IN: PERICÁS, Luiz Bernardo; SECCO, Lincoln (orgs.). 
Nesse tempo, em que era criado um importante órgão partidário representativo do período de agrura social e mobilização política, Nathan e Anna concebem o seu primeiro filho, Jacob Gorender. O rebento nasceu em 20 de janeiro de 1923, em Salvador, sendo registrado pelo seu pai no distrito da Sé. ${ }^{17} \mathrm{O}$ menino Jacob nasce em um cenário no qual os imigrantes judeus "tratavam de se aclimatar o mais depressa possível". ${ }^{18}$ Essa iniciativa de "assimilação" aos costumes locais passa pela tradução de palavras e nomes próprios mais apropriados ao comum ofício de "venda a prestação", praticado lá por judeus, o qual guardava relação com algumas atividades econômicas que exerciam alhures. Moravam, via de regra, em bairros de classe média ou em casas mais simples, de condições mais precárias. Os Gorender, de acordo com a memória de Jacob, eram residentes do segundo tipo de moradia:

Os cinco filhos e meus pais pertenciam àquela categoria dos judeus sem dinheiro, descritos num romance de Michael Gold, célebre nos anos 30. Morávamos em cortiços e, às vezes, tínhamos dificuldades sérias até para atender necessidades elementares, como alimentação e roupa. Isso marcou minha mentalidade em formação. Mas, não só isso: meu pai era um homem de esquerda, antissionista - como, aliás, a maioria dos judeus daquela época - e me falava do movimento revolucionário russo. Fizera apenas o curso primário, mas lia avidamente. Exerceu forte influência nas minhas inclinações. ${ }^{19}$

Boris Tabacof - também nascido em Salvador, filho de imigrantes judeus relatou que sua família residia na Rua da Misericórdia, em proximidade à Praça da Sé. Dado que Nathan e Anna Gorender registraram o seu filho no distrito da Sé, é correto supor que residiam em sua proximidade, ou seja, em um núcleo central. Possivelmente próximos dos Tabacof, talvez mesmo em uma vizinhança judia.

Em tais entornos que os judeus possivelmente costumavam se concentrar, na região do Campo da Pólvora, seio da formação do ishuv - o bairro de Nazaré. Possível bairro judeu que reunia os clienteltchik e pekl, vendedores ambulantes que proviam os centros de mercadorias, os quais estão na base do florescimento de uma vida judaica na Cidade da Bahia. A família dos Gorender certamente se relacionou com o caldo cultural que ali germinava.

Poucos meses depois do nascimento de Jacob Gorender é fundada a Sociedade Beneficente Israelita da Bahia (SBIB). Vinha atender uma demanda tradicional dos judeus de Salvador, população crescente nas primeiras décadas do século XX. ${ }^{20}$ Com relação à comunidade judaica, no Art. 2 da SBIB, dos "principaes interesses da Sociedade", estão previstas a fundação de uma sinagoga, uma biblioteca, e, no parágrafo terceiro: "Fundar e manter uma escola judaica, a fim de ministrar aos filhos dos associados, uma educação judaica além da educação geral que os mesmos adquirirem nas escolas brasileiras." ${ }^{21}$

A escola que pretendiam construir foi fundada em 1924, com o nome de Escola Israelita Brasileira Jacob Dinenzon. Em seu currículo, além das disciplinas

Intérpretes do Brasil: clássicos, rebeldes e renegados. São Paulo: Boitempo, 2014. pp.13-25.

17 REGISTRO CIVIL DO DISTRITO DA SÉ. Certidão de Nascimento de Jacob Gorender. Bahia: 21/01/1923. Memorial da Faculdade de Direito - FD/UFBA. Documentação Acadêmica de Jacob Gorender.

18 TABACOF, Boris. Perdidos e achados. São Paulo: Editora Hucitec, 2005. p.21.

19 GORENDER, Jacob. “Entrevista realizada por Alípio Freire e Paulo de Tarso Venceslau”. Teoria e Debate, n.11, agosto de 1990, p.21

20 GORENDER, Jacob. “Entrevista realizada por Marcelo Ridenti e Alípio Freire”. Margem Esquerda, n.9, junho de 2007, p.14.

21 "A pedidos - Estatutos da Sociedade Beneficente da Bahia". Diário Oficial, terça-feira, 23 de agosto de 1923. AHJB, Seção Bahia. 
regulares, constavam os cursos de Hebraico, lídiche, História e Literatura Judaica até $05^{\circ}$ ano primário. ${ }^{22}$ Atendia a um objetivo duplo, em que se buscava tanto preservar as tradições judaicas quanto preparar os jovens membros da comunidade às competências necessárias para a prosperidade no local de residência. Dentre essas competências, é destacada a admissão no Ginásio da Bahia. ${ }^{23}$

É possível que os conteúdos específicos da cultura judaica tenham uma função importante na formação de Jacob Gorender, especialmente se for assumida a hipótese de que alguma educação, referente ao tema tenha recebido no interior de seu lar. Nos escritos de Tabacof, referentes à sua vida familiar, é destacada a atenção da comunidade judaica local com "a educação e a cultura de tradição europeia", onde "não havia judeus analfabetos, por mais destituídos que fossem", devido à necessidade de observação dos ritos sagrados, pautados pela leitura. ${ }^{24}$

Primeira escola secundária surgida no Brasil, o Ginásio da Bahia possuía destaque no ensino público baiano, abrigando em seus bancos alunos de variadas origens sociais, admitindo os mesmos por meio de exame classificatório. Jacob Gorender foi um dos que estudou nesse importante estabelecimento, de acordo com o objetivo desenvolvido pela comunidade judaica na Escola Jacob Dinenzon de encaminhar as suas crianças em bom posto local de ensino.

A predominância social no Ginásio da Bahia, de acordo com depoimentos de ex-alunos, era das "camadas médias da população de Salvador". ${ }^{25}$ A taxa de matrícula para frequentar a instituição de ensino não era cara, já que os cinco irmãos da família Gorender estudavam pagando os seus custos. ${ }^{26}$ Jacob, o filho mais velho, para auxiliar nos vencimentos de sua casa, aos 11 anos já trabalhava dando aulas particulares.

A partir de 1936, quando Gorender tinha 13 anos e já integrava o corpo discente do Ginásio da Bahia, era facultado aos alunos o Programa de Curso Complementar, regulamentado pelo Decreto n. ${ }^{\circ}$ 9.833. Três novos cursos eram então abertos aos educandos: a) Jurídico; b) Engenharia; c) Medicina. As opções se alinhavam com as principais carreiras superiores seguidas pelos jovens melhor aquinhoados. Cursou as disciplinas do Curso Complementar, concluindo o "PréJurídico" em 1940. Seguem os conteúdos integrantes desse curso:

Quadro 1: Carga horária do Curso Jurídico do Ginásio da Bahia (1936)

\begin{tabular}{l|l}
\hline Primeira série & Segunda série \\
\hline Latim (6 horas) & Latim (6 horas) \\
\hline Literatura (6 horas) & Literatura (4 horas) \\
\hline História da Civilização (4 horas) & Geografia (3 horas) \\
\hline Noções de Economia e Estatística (4 horas) & Higiene (3 horas) \\
\hline Biologia Geral (3 horas) & Sociologia (4 horas) \\
\hline Psicologia e Lógica (4 horas) & História da Filosofia (4 horas) \\
\hline
\end{tabular}

Fonte: Quadro reproduzido de: LIMA, Déborah. “O Banquete Espiritual da Instrução”: O Ginásio da Bahia, Salvador: 1895-1942. (Dissertação de mestrado em História, Universidade Federal da Bahia, 2003), p.52.

Só foram encontrados os resultados médios que Gorender alcançou em seu último ano de Jurídico. Suas melhores notas então foram em Literatura

22 Relatório das atividades da Sociedade Israelita da Bahia (Julho 1969 - Março 1970). AHJB, Seção Bahia.

23 TABACOF. Perdidos e achados, p.24

24 TABACOF. Perdidos e achados, p.22.

25 LIMA, Déborah. ““'O Banquete Espiritual da Instrução”: O Ginásio da Bahia, Salvador: 1895-1942”. (Dissertação de mestrado em História, Universidade Federal da Bahia, 2003), p.97-100.

26 GORENDER, apud LIMA. "O Banquete Espiritual da Instrução”, p.100. 
(86), Sociologia (81) e Geografia (79). A sua nota de conjunto foi de número 79. ${ }^{27}$ Algumas informações sobre as aulas de Literatura ali ministradas são conhecidas através de seu programa de ensino. Provavelmente a segunda disciplina em importância (apenas Latim possuía mais horas semanais de estudo), era composta por um robusto programa, o qual compreendia do estudo de gêneros e estilos literários aos cânones da literatura ocidental e oriental. Filósofos, ensaístas, críticos e historiadores estavam presentes nessas eruditas aulas. ${ }^{28} \mathrm{~A}$ partir dessas informações cabe seguir a suposição de Lima acerca do perfil de aluno que se almejava: o "intelectual universal":

A educação dos discípulos do GB, destarte, advinha do paradigma, que elegeu o homem culto como signatário da resolução dos problemas da sociedade. Neste diapasão o educandário objetivava formar alunos aplicados e oradores eruditos, através de uma concepção ligada ao sujeito universal, identificado como masculino e branco. ${ }^{29}$

Gorender situava-se na classe popular soteropolitana, porém pôde obter acesso a um ensino tido como "de elite", pois aparelhado com professores de destaque e reconhecido pelo exame de admissão exigente - um indício é o dado que, em 1940, apenas 39,6\% dos candidatos foram aprovados. ${ }^{30}$

Ainda que tenha frequentado uma instituição de ensino reconhecida, ou justamente pelo contraste social com alguns de seus colegas de classe, Jacob Gorender, já quase um septuagenário, atribuirá a sua "predisposição" às ideias marxistas a um "sentimento anticapitalista" seu juvenil decorrente de sua situação de pobreza desde a infância. As dificuldades vividas em seu lar são ressaltadas em diversos momentos em que dispõe a falar de si. Nas suas palavras: "A minha família era paupérrima, por diversas circunstâncias. Cheguei a passar fome, tive alimentação deficiente, que influenciou minha saúde, pois fiquei enfraquecido." 31

Se aceita a afirmação do próprio Gorender de que era "predisposto ao marxismo" pela sua pobreza, cabe ressaltar que antes de Marx, contudo, teve contato com outro grande nome de ciências europeu: Charles Darwin. Contato inicial que foi indireto, por meio de um seguidor e popularizador de seu pensamento, o alemão Ernst Haeckel.

O nome de Haeckel também comparece nas memórias da adolescência de Leôncio Basbaum: "[...] foi também nessa pequena mas escolhida biblioteca que comecei a ler a obra dos materialistas alemães, principalmente Haeckel e a dirigir o meu espírito curioso para a ciência e a filosofia, principalmente o materialismo". ${ }^{32} \mathrm{O}$ militante pernambucano relata, no mesmo texto, ter encontrado a obra do autor na biblioteca de seu irmão mais velho, José, espaço esse em que se formava enquanto leitor, conhecendo literatura brasileira, portuguesa e francesa. É também na coleção de José Basbaum, agora no que tange aàs revistas então em circulação, que Leôncio fica sabendo do bolchevismo, retratado de forma monstruosa. ${ }^{33}$

27 MINISTÉRIO DE EDUCAÇÃO E SAÚDE. Certificado de conclusão do Curso Complementar - 2ª ano pré-jurídico, Jacob Gorender. Ginásio da Bahia. 1940. Memorial da Faculdade de Direito - FD/UFBA. Documentação Acadêmica de Jacob Gorender.

28 Programa de Literatura do Curso Jurídico do Ginásio da Bahia - 1936, apud LIMA, Déborah. “O Banquete Espiritual da Instrução", p.159-163.

29 LIMA. "O Banquete Espiritual da Instrução”, p.52.

30 GORENDER, apud LIMA. "O Banquete Espiritual da Instrução", p.105.

31 GORENDER. "Entrevista realizada por Marcelo Ridenti e Alípio Freire", p.14.

32 BASBAUM. Leôncio. Uma vida em seis tempos (memórias). São Paulo: Editora Alfa Ômega, 1976, p.24.

33 BASBAUM. Uma vida em seis tempos, p.24. 
Um segundo momento das memórias de Leôncio Basbaum também pode ser ilustrativo para a trajetória de Jacob Gorender. Dezesseis anos mais velho que Gorender, Basbaum residia em Salvador como gerente da rede de lojas de seu irmão, enquanto Jacob ainda era um adolescente. Provavelmente, a despeito da diferença de idade, guardavam alguma afinidade de gostos e interesses quanto à leitura, afinal, ambos recordaram Haeckel entre os autores materialistas com que primeiro travaram contato, em momentos distintos. O testemunho de Basbaum com relação às suas procuras científicas nas livrarias da capital baiana, portanto, pode revelar possibilidades e limitações na difusão de escritos com que Gorender pode ter se deparado:

[...] na Bahia não era fácil encontrar obras de Marx e Engels e dos marxistas clássicos, nem mesmo de Lenine. Aqui ou ali se encontrava algum em francês, ou em língua espanhola edições argentinas de Claridad, uma editora de esquerda, de tendência trotskista. Mas era do que eu me alimentava. E, além disso, tudo o que encontrava sobre a História da Filosofia, sobre ciência, principalmente Física e Biologia. ${ }^{34}$

É pela compra de livros nos sebos da Praça da Sé que Gorender alega ter travado contato com as ideias materialistas. Com doze anos, leu Haeckel, o qual the "transformou". Já com quatorze anos, aderiu ao darwinismo e enfim travou contato direto com "A origem das espécies". Esta pode ser considerada a sua iniciação em tal corrente filosófica, bem como um marco de contradição com a religião familiar, momento em que abandona tal prática35.

Não há informações, também, acerca de possíveis influências de uma "imaginação judaica” a povoar os pensamentos do jovem Gorender, como o relatado pela escritora Tamara Deutscher com referência ao seu esposo, Isaac Deutscher. ${ }^{36}$ Gorender, porém, afirmou em uma entrevista que "[...] o fato de ser judeu exerce uma influência sobre meu modo de ver as coisas e a cultura". ${ }^{37} \mathrm{Em}$ que a sua pertença étnica, e tudo que isso possivelmente implica, pode ter influenciado sua visão de mundo? Cabe retomar o já citado exemplo de Deutscher. Em um texto com o título "Quem é judeu?", o autor se vale, dentre outros sujeitos e coletividades, de sua própria vivência e ideias para pensar o problema da identidade judaica no mundo pós-holocausto. Descarta, como definidores identitários, o nacionalismo, a raça e a religião. O que faz, então, de Deutscher um judeu?

Sou judeu, entretanto, pela força de minha incondicional solidariedade aos perseguidos e exterminados. Sou judeu porque sinto a tragédia judaica como a minha própria tragédia; porque sinto o pulsar da história judaica; porque daria tudo que pudesse para assegurar aos judeus autorrespeito e segurança reais e não fictícios. ${ }^{38}$

Ainda que exista algo de idealista na resposta de Deutscher é possível apreender determinações objetivas em alguns dos elementos que este autor cita. Escrever sobre o tema pouquíssimo tempo depois do término da Segunda Guerra, com nítidas lembranças de pogroms em sua infância, certamente o influenciou a

34 BASBAUM. Uma vida em seis tempos, p.161. Grifo no original.

35 GORENDER. "Entrevista realizada por Alípio Freire e Paulo de Tarso Venceslau”, p.21; GORENDER. "Entrevista realizada por Marcelo Ridenti e Alípio Freire", p.14.

36 DEUTSCHER, Tamara. "Introdução - A educação de uma criança judia". IN: DEUTSCHER, Isaac. O judeu não judeu e outros ensaios. Rio de Janeiro: Civilização Brasileira, 1970, p.7-26.

37 GORENDER. "Entrevista realizada por Marcelo Ridenti e Alípio Freire", p.14.

38 DEUTSCHER. O judeu não judeu, p.49. 
perceber a sua "incondicional solidariedade". A memória e a experiência - um enraizamento de caráter mais temporal do que espacial - cumprem um papel essencial nessa definição identitária. ${ }^{39}$ Não seria Jacob Gorender também um judeu - no sentido de alguém que "vê as coisas e a cultura" de modo influenciado por essa identidade - por causa da sua memória familiar das condições de dupla opressão que sofreram? As memórias no seu lar (combinadas às experiências de exploração econômica no Brasil), bem como as notícias do antissemitismo na Europa, não podem ter orientado a sua visão de mundo em construção?

As condições materiais pobres da família Gorender, a criação na comunidade judaica soteropolitana e as reflexões materialistas animadas por Darwin e Haeckel, que levaram Jacob a tornar-se um ateu (ainda que inserido na identidade étnica judia), ${ }^{40}$ constituíram "um caminho" possível para ele ao marxismo, o qual não foi linear.

As ideias de autores do pensamento científico do século XIX (dentre esses, Ernst Haeckel), de acordo com Cláudio Batalha, passaram por um processo de apropriação eclética na tradição socialista brasileira, o qual integrava o pensamento e propostas socialistas (especialmente pela via de Marx) com a de outros pensadores temporalmente próximos, como Comte e Spencer, por exemplo. ${ }^{41} \mathrm{~A}$ tendência por uma leitura eclética de Marx possuiu alguma continuidade na militância do início do século XX, "afinidade eletiva"42 entre o cientificismo e um nascente marxismo que pode ter ocorrido também nas primeiras aproximações que Jacob Gorender trava com os escritos propriamente marxistas.

Essas leituras de Gorender foram praticadas em sua adolescência. Ou seja, era um rapaz que travou contato com textos, nas suas palavras, "materialistas e evolucionistas", em um contexto de grande conturbação. Era meados dos anos 1930, década marcada pela escalada do fascismo na Europa e as possibilidades de modernização, com variadas formas possíveis, no Brasil. Foram, em suma, tempos de agressiva disputa, a qual se expressou nas diferentes organizações a disputarem a hegemonia daquele espaço.

No que toca o jovem PCB, tornado ilegal não muito tempo depois da fundação, guiado pelo programa revolucionário de ruptura com as amarras do "agrarismo" e do imperialismo, preconizou a formação de uma aliança das massas trabalhadoras, do campo e da cidade, por meio do Bloco Operário Camponês (BOC). Poucos anos depois, na voga dos militares mobilizados na década de 1920, mas contrários aos rumos do governo inaugurado em 1930, formou-se a Aliança Nacional Libertadora (ANL). O movimento marcou uma transição programática para os comunistas brasileiros. O caráter quase que exclusivamente proletário do partido sofreu sensível modificação quando uma série de militares ingressou em suas fileiras.

39 Boris Tabacof, por exemplo, ao escrever sobre os imigrantes judeus na Bahia, lembra que os caminhos que os integrantes dessa comunidade seguiram "[...] recuam para um passado muito distante, e mesmo os que não conheciam essa história milenar de maneira mais clara tinham a consciência de pertencer a uma corrente ininterrupta que valia a pena preservar." Cf: TABACOF. Perdidos e achados, p.26.

40 GORENDER. “Entrevista realizada por Marcelo Ridenti e Alípio Freire”, p.14.

41 BATALHA, Cláudio. "A difusão do marxismo e os socialistas brasileiros na virada do século XIX”. In: MORAES, João Quartim (org.). História do marxismo no Brasil. Vol. 2: Os influxos teóricos. Campinas: Editora da Unicamp, 2007, p.11-12.

42 "Designamos por "afinidade eletiva" um tipo muito peculiar de relação dialética que se estabelece entre duas configurações sociais ou culturais, não redutível à determinação causal direta ou à "influência" no sentido tradicional. Trata-se, a partir de uma certa analogia estrutural, de um movimento de convergência, de atração recíproca, de confluência ativa, de combinação capaz de chegar até a fusão. Em nossa opinião, seria interessante tentar fundar o estatuto metodológico desse conceito, como instrumento de pesquisa interdisciplinar que permite enriquecer, nuançar e tornar mais dinâmica a análise das relações entre fenômenos econômicos, políticos, religiosos e culturais." (f: LÖWY, Michael. Redenção e utopia. O judaísmo libertário na Europa Central (um estudo de afinidade eletiva). São Paulo: Companhia das Letras, 1989, p.13. 
A condensação das mudanças ocorridas na ação comunista se deu em novembro de 1935 com um levante da ANL ocorrido em Natal, Recife e Rio de Janeiro. A deflagração se deu no âmbito dos quartéis, a partir da iniciativa dos militares que aderiram à ideia da revolução nacional-popular. A IC tinha interesses nessa tentativa revolucionária, mobilizando agentes para a sua consecução. Derrotado o movimento, não tardou a reação.

Sendo o principal alvo da repressão que se seguiu aos ocorridos de 1935, o PCB foi bastante abatido. O núcleo dirigente sediado no Rio de Janeiro, bem como em São Paulo, sofreu particularmente tal processo. Em outras regiões do país, porém, as prisões não foram tão acentuadas. O Nordeste tornou-se uma "rota de fuga" para a nova direção nacional - Lauro Reginaldo da Rocha, o "Bangu”, era o novo secretário-geral - esforçada na rearticulação dos comitês regionais de lá. ${ }^{43}$

Os comunistas, que originalmente se instalaram em Recife, em junho de 1936, dois meses depois precisaram debandar para Salvador. A capital baiana foi o espaço onde a inflexão tática do PCB tomou corpo, com o documento "A marcha da revolução nacional libertadora e suas forças motrizes". ${ }^{44}$ Procuravam aproximar-se com setores da oposição a Getúlio Vargas e construir uma "frente única, democrática e popular”. Combinavam-se, então, o balanço político dos dirigentes, frente os malfadados efeitos de 1935, com as orientações do VII Congresso da IC, no mesmo ano, no qual há uma transição tática dos órgãos revolucionários em direção à "frente popular".

Salvador foi escolhida para abrigar o órgão dirigente do Partido Comunista do Brasil, em boa medida, pelos efeitos pífios de 1935 lá, dada a fraqueza local do PCB, com pouquíssima militância. Diógenes de Arruda Câmara, importante comunista que atuou em Salvador quando jovem, relatou em sua maturidade sobre a situação local do PCB nos anos 30, destacando a fraqueza organizativa, especialmente nos episódios de 1935.45 Leôncio Basbaum, que se encontrava então em Salvador, testemunhou que a "reorganização" do PCB seria muito mais um esforço de "organização", pois este não possuiria bases fortes locais. ${ }^{46}$ Se até então o Partido Comunista na Bahia era fraco, a partir do momento em que Salvador tornou-se um novo centro decisório nacional, o órgão cresceu fortemente, especialmente o Comitê Regional, o qual contou com jovens estudantes e representativos trabalhadores locais além dos já destacados membros que para lá rumaram em fuga dos arbítrios policiais.

Era um espaço de maior liberdade para os comunistas, afinal, além de sua então inexpressividade ali, também pelo próprio fato do destaque que os integralistas baianos possuíam, a repressão lhes foi menos pesada. Os comunistas, tendo a Bahia como seu novo centro político, dão novos passos organizativos não só tendo em vista uma vindoura rearticulação nacional, mas também revitalizando a sua atuação naquele estado. O movimento estudantil era um dos seus caminhos.

Já ocorria uma articulação de sujeitos envolvidos na constituição de células estudantis do Partido Comunista entre os discentes locais, como Armênio Guedes

43 SENA JÚNIOR, Carlos Zacarias. Os impasses da estratégia. Os comunistas, o antifascismo e a revolução burguesa no Brasil. 1936-1948. São Paulo: Annablume, 2009. p.35.

44 Com este texto, de acordo com Sena Júnior: "a direção comunista alterava substancialmente sua forma de ver o processo da revolução no Brasil, a partir da consideração do que seriam seus próprios erros e da compreensão de que teria havido uma importante alteração conjuntural ainda sob o governo Vargas, o que proporcionaria as condições para uma modificação na linha até então praticada." Cf: SENA JÚNIOR. Os impasses da estratégia, p.41-42.

45 CÂMARA, Diógenes de Arruda apud SENA JÚNIOR. Os impasses da estratégia, p.50.

46 BASBAUM. Uma vida em seis tempos, p.165. 
e Diógenes Arruda Câmara. Guedes era estudante de Direito; Diógenes Arruda era pernambucano, trabalhava para o Ministério do Trabalho e cursava Agronomia em Salvador. Arruda Câmara, que à época já tinha destaque nas articulações regionais, foi visado pela repressão e preso tanto em 1937 (com o golpe do Estado Novo), quanto em 1940, momento em que os comunistas baianos possuem enorme visibilidade, tanto pela militância quanto pela polícia. ${ }^{47}$

Ainda que o PCB florescesse (ou, melhor expresso, sobrevivesse) mais na Bahia do que em outros territórios nacionais, não foi sem dificuldades que os comunistas tiveram que atuar ali. Uma das possibilidades mais frutíferas de atuação política postas ao partido se encontrava na formação dos estudantes locais, categoria em que se encontrava Jacob Gorender, futuro aluno da Faculdade de Direito de Salvador.

\section{"Vestindo calças compridas": Faculdade de Direito, movimento estudantil e o PCB em tempos de União Nacional}

O ensino superior brasileiro nos anos 1940, para os poucos que podiam acessá-lo, praticamente se resumia aos cursos de Medicina, Engenharia e Direito. Foi pela última carreira que Jacob Gorender optou, ingressando na Faculdade de Direito de Salvador em $1941 .^{48}$ Não iniciou seus estudos logo após o término do Curso Complementar, pois, a despeito das notas satisfatórias, o estudante não tinha renda para a atividade intelectual. A solução veio com um emprego no jornal O Imparcial, 49 atividade que lhe garantiu soldo suficiente para possibilitar o acesso aos estudos superiores um ano depois. Em 26 de janeiro de 1942 pagou a quantia de $160 \$ 000$ de inscrição para o concurso de habilitação à Faculdade de Direito..$^{50}$ Aprovado, teve contato não só com leituras e aulas, mas, principalmente, com a agitação comunista.

No mesmo ano conheceu o jovem Mário Alves, aluno do curso de Ciências Sociais e militante do Partido Comunista do Brasil. De origem abastada, Alves iniciou sua participação no movimento comunista em 1939, ainda estudante no Ginásio da Bahia, em um contexto de enorme radicalização - enquanto o Estado Novo exercia repressão, jovens e trabalhadores se mobilizavam por circunstância das agitações contra a guerra em início, via de regra marcados por posições político-ideológicas extremadas: de um lado, o integralismo brasileiro; de outro, a influência do socialismo como oposição à ordem instituída e, principalmente, à ofensiva fascista internacional. ${ }^{51}$

Mário Alves recrutou Jacob Gorender para o PCB em circunstâncias clandestinas, como cabia a um partido ilegal e perseguido em tal conjuntura. De acordo

47 SENA JÚNIOR. Os impasses da estratégia, pp.97-99.

48 Nas entrevistas em que a sua trajetória estudantil é objeto de discussão, Jacob Gorender menciona sem vacilar a sua passagem na Faculdade de Direito de Salvador. Na sua documentação acadêmica, porém, todos os registros oficiais são registrados como da Faculdade de Direito da Bahia. Doravante, neste texto, no que toca a citação de documentação, a discrepância será resolvida pelamenção à Faculdade de Direito da Bahia, concernente aos documentos oficiais.

49 O Imparcial era um jornal que se inseria no que é chamado de a "grande imprensa na Bahia", ao lado de outros veículos como Diário da Bahia, A Tarde e Diário de Notícias. Cf: FERREIRA, Laís. Integralismo na Bahia. Gênero, Educação e Assistência Social em O Imparcial 1933-1937. Salvador: EDUFBA, 2009.

50 FACULDADE DE DIREITO DA BAHIA. Guia Nº. 9408. Bahia, 26 de janeiro de 1942. Memorial da Faculdade de Direito - FD/UFBA. Documentação Acadêmica de Jacob Gorender.

51 FALCÓN, Do reformismo à luta armada, p.83. 
com suas memórias, após ingressar no curso de Direito passou a atuar na União de Estudantes da Bahia (UEB), integrando a sua direção, o que chamou a atenção de Mário Alves. ${ }^{52}$ Constituíram uma célula estudantil Alves, Gorender e Ariston Andrade. Gorender ressalta que havia concluído a escola tocado por "[...] outras ideias, com um universo mais amplo", as quais remete ao período de agitação logo de seu ingresso no partido, especialmente no que toca aos movimentos populares que agitaram Salvador devido o torpedeamento de navios no litoral devido à guerra em curso. ${ }^{53}$

A conjuntura de marcada polarização política, ao que tudo indica, constituiu uma marca geracional para esses jovens comunistas. Se antes já era possível que se encontrassem apreensivos com a situação estrangeira, com a entrada da União Soviética na guerra, em junho de 1941, a visão dos comunistas acerca do conflito foi transformada. A Conferência do Nordeste, ocorrida em Salvador, ao final do ano de 1941, foi uma iniciativa do Comitê Regional baiano que contou com a participação de representantes de Sergipe, Alagoas e Pernambuco. É ali que foi aprovada a tática política de União Nacional para combate ao inimigo comum - nazismo em âmbito global, o Estado Novo em solo brasileiro. Essa resolução assumiu importante papel para a jovem militância atuando em Salvador (e para os rumos de todos os que ainda restaram no partido em nível nacional). ${ }^{54}$

Recém-inserido no órgão que se propunha liderar o povo unido contra o inimigo nacional, Jacob Gorender também encontrou algum tempo para dedicação aos estudos superiores, já orientado pelo "universo mais amplo de ideias" com que vinha tendo contato gradualmente. Os boletins de Jacob Gorender de 1942 e 1943, primeiro e segundo ano de faculdade, indicam um estudante que era aprovado via de regra na média, dedicando-se mais a certas disciplinas do que a outras. Segue exposição de sua matrícula e frequência nas referidas seriações:

\section{Quadro 2: Prova de matrícula e frequência do primeiro ano da Faculdade de} Direito da Bahia

\begin{tabular}{l|c|c}
\hline Cadeiras & N.o de aulas & Faltas \\
\hline Introdução à Ciência do Direito & 110 & 6 \\
\hline Economia Política & 66 & 12 \\
\hline Direito Romano & 67 & 13 \\
\hline Teoria Geral do Estado & 71 & 7 \\
\hline
\end{tabular}

Fonte: FACULDADE DE DIREITO DA BAHIA. Prova de matrícula e frequência de Jacob Gorender no primeiro ano da Faculdade de Direito da Bahia. Bahia: 24 de novembro de 1942. Memorial da Faculdade de Direito FD/UFBA. Documentação acadêmica de Jacob Gorender.

52 GORENDER. "Entrevista realizada por Alípio Freire e Paulo de Tarso Venceslau", p.22.

53 GORENDER apud FALCÓN. Do reformismo à luta armada, p.83.

54 FALCÃO, João. O Brasil e a Segunda Guerra Mundial: testemunho e depoimento de um soldado convocado. Brasília: Editora UNB, 1999, p.56-57. 
Quadro 3: Prova de matrícula e frequência do segundo ano da Faculdade de Direito da Bahia

\begin{tabular}{l|c|c}
\hline Cadeiras & N.o de aulas & Faltas \\
\hline Direito Civil & 55 & 5 \\
\hline Direito Penal & 58 & 3 \\
\hline Direito Constitucional & 54 & 8 \\
\hline Ciência das Finanças & 62 & 16 \\
\hline
\end{tabular}

Fonte: FACULDADE DE DIREITO DA BAHIA. Prova de matrícula e frequência de Jacob Gorender no segundo ano da Faculdade de Direito da Bahia. Bahia: 23 de novembro de 1943. Memorial da Faculdade de Direito FD/UFBA. Documentação acadêmica de Jacob Gorender.

Possivelmente o regimento da faculdade abria brechas ao número de faltas acentuado em certas disciplinas de carga horária menor e exigia, por outro lado, presença constante em outros cursos. O grau de exigência de cada conteúdo também pode ser uma explicação para a disparidade de frequências. Chama a atenção, porém, o fato que Gorender, em seu ano de calouro, pouco faltou às aulas de "Teoria Geral do Estado" e "Introdução à Ciência do Direito". Pelo número de horas-aula, supõe-se que essa última disciplina era tida como de maior centralidade que as outras dos primeiranistas. "Teoria Geral do Estado", contudo, ainda que pareça estar no mesmo nível de valorização oficial que "Economia Política" e "Direito Romano", teve um grau de ausência bastante menor do que essas últimas. Assumindo a probabilidade que o regimento interno permitisse frequência folgada em tal curso, assim como nos de horas-aula correlatas, é possível que Gorender tivesse um interesse maior nos conteúdos ministrados nessa aula, onde pode ter sido oportunizada a leitura e discussão de importantes autores que discutiram fenômenos políticos, assunto de interesse para o aluno que então iniciava uma atuação militante.

Entre as suas obrigações, Jacob Gorender também se deparou com a célula estudantil da qual fez parte, entidade que era de responsabilidade direta dos envolvidos, dos locais para reuniões ao funcionamento orgânico. Era um espaço de articulação dos alunos comunistas, servindo para tocarem a atuação partidária e organizarem as suas candidaturas a cargos nas variadas entidades estudantis locais, onde faziam o chamado trabalho em frente legal junto às massas. Já o trabalho ilegal, clandestino, era feito no âmbito direto do partido, regido sob outras hierarquias e envolvendo maiores dimensões.

A composição inicial de uma célula estudantil era a seguinte: secretário, tesoureiro e agitprop. Falcão narra que duas eram as recomendações dos comunistas mais experimentados: cautela com os alunos que possivelmente espionassem os colegas para a Delegacia da Ordem Pública e Social, e a leitura de Os Fundamentos do Leninismo, de Joseph Stalin, com especial atenção no capítulo dedicado ao partido. 55

Um novo modo de vida e uma nova visão de mundo se abriam a Gorender. Não cabe, porém, entender esse processo como uma completa ruptura com a trajetória dele até então. Caminhos para a possibilidade de "ser comunista" se anunciaram em momentos já acompanhados neste texto. Outros jovens que vivenciavam o conturbado contexto dos anos 1940 também podem ter recebido tal convite. Tantos devem tê-lo recusado. A sua adesão ao marxismo, portanto, não foi uma

55 FALCÃO, João. O Partido Comunista que eu conheci (20 anos de clandestinidade). Rio de Janeiro: Editora Civilização Brasileira, 1988, p.40-42. 
inevitabilidade. Cabe, sim, discutir quais fatores podem ter levado Jacob Gorender a tornar-se um comunista e os significados disso para si e suas relações sociais. Jorge Ferreira, que se interrogou acerca do imaginário político dos comunistas, refletiu sobre a presença de "simbologia mítica" em tal militância:

\footnotetext{
Outros militantes, no entanto, procuravam racionalizar, com maior sistematização, o envolvimento com o partido. Para Osvaldo Peralva, "numerosos e vários são os caminhos que levam ao comunismo". Giocondo Dias, em busca de certa precisão, descreve três caminhos básicos: "chega-se ao partido pelo estômago, pela cabeça ou pelo coração." 56
}

O trecho escolhido de Giocondo Dias ajuda a pensar as influências possíveis nos caminhos trilhados por Gorender. Seguindo a analogia de Dias, os três órgãos vitais (estômago, cabeça e coração) podem ser encontrados em numerosas referências nas entrevistas já citadas do biografado: sua infância pobre, a influência paterna, leituras materialistas, o senso de solidariedade, etc. Com um pouco de liberdade poética, pode-se argumentar que também "os pés no chão" desse jovem, sua inserção em um espaço e tempo específicos, ajudam a explicá-lo.

Além de interrogar sobre as razões que levaram Jacob Gorender a aceitar o convite de Mário Alves para integrar o Partido Comunista, cabe atentar o que era, então, ser comunista. Eric Hobsbawm, no que toca à militância no auge da IC, apresenta um "exército mundial da revolução", uma consciência presente naqueles que passavam a atuar no movimento comunista internacional de executarem uma "única e ampla estratégia da revolução mundial". Convicção moral, de acordo com o historiador. ${ }^{57} \mathrm{Em}$ tempos de enfrentamentos bélicos e ideológicos acirrados, é razoável supor que essa consciência também era presente para Gorender e seus camaradas.

Com qual movimento comunista o estudante de Direito se deparou? Já foi mencionada a nova linha tática de União Nacional, resolução do PCB criada tendo em vista os perigos da guerra no estrangeiro. Mas, em âmbito local, em Salvador, qual era a estrutura partidária em que Gorender inicia um processo de inserção?

Os espaços de atuação possível para os comunistas baianos dividiam-se entre as organizações estudantis e as de trabalhadores. A presença de células comunistas, no final dos anos 30, se dava em algumas escolas, como o caso do Ginásio Carneiro Ribeiro. No ensino superior, o Centro Acadêmico e Diretório Acadêmico constituíam instituições em que a política deveria ser praticada. A Associação Universitária da Bahia (AUB) era lócus privilegiado dos estudantes comunistas, pois centralizava as demandas estudantis. ${ }^{8}$ Sena Júnior afirmou existirem sete células estudantis (Faculdades de Direito, Medicina, Agronomia, Engenharia, Eletromecânica, Ciências Econômicas, além dos Ginásios da Bahia e Carneiro Ribeiro) e treze células de trabalhadores (portuários, força e luz, panificadores, gráficos, sapateiros, barbeiros, ferroviários, tecelões, fumageiros, comerciários, construção civil, alfaiates, etc.) em Salvador. ${ }^{59}$

Estudante de Direito, repórter na imprensa local e militante do Partido Comunista, Jacob Gorender era mais um jovem que "trocava suas calças curtas

\footnotetext{
56 FERREIRA, Jorge. Prisioneiros do Mito. Cultura e imaginário político dos comunistas no Brasil (1930-1956). Niterói/Rio de Janeiro: EdUFF; Mauad, 2002, p.61.

57 HOBSBAWM, Eric. Revolucionários. Rio de Janeiro: Paz e Terra, 1985, p.17.

58 FALCÃO. O Partido Comunista que eu conheci, p.41-42.

59 SENA JÚNIOR. Os impasses da estratégia, p.98-99.
} 
pelas calças compridas". A metáfora - utilizada pelo próprio ${ }^{60}$ - referia-se ao amadurecimento, a deixar a adolescência e ingressar na fase adulta, de responsabilidades. Entre as ações que Gorender, "vestindo as calças compridas", passa a desempenhar enquanto um militante do Partido Comunista na juventude soteropolitana, para além de sua já citada participação nas organizações estudantis constituídas e legalizadas, destaca-se a sua atuação entre os colaboradores na revista Seiva. Criada em 1938, por iniciativa do também jovem militante João Falcão, era uma publicação alinhada ao "pensamento do movimento democrático e antifascista na Bahia e no Brasil", com vistas a um papel de alcance na intelectualidade nacional, sob a direção do $\mathrm{PCB} \cdot{ }^{61} \mathrm{~A}$ formação de Seiva se processou em uma conjuntura de valorização do papel cumprido pelo Comitê Regional baiano nos quadros do Partido Comunista, bem como em correspondência com as definições de tática e de estratégia vigentes então no PCB quanto aos cuidados necessários para escapar à censura do Estado Novo.

Seiva logrou sucesso: era a única publicação (secretamente) comunista de circulação ampla e livre no Brasil. Isso se devia ao seu caráter moderado, que não atacava o Catete, restringindo a sua oposição à reivindicação pela democracia. Sofreu alterações, porém, com o seu segundo ano de existência, a partir da invasão que as tropas de Hitler fizeram na Polônia. Estourava uma nova guerra, os comunistas precisavam intervir na realidade com maior afinco. Os comunistas baianos ampliaram o destaque que já possuíam no seio do partido. ${ }^{62}$

Sob essa conjuntura, logo do ano de seu recrutamento para o PCB, Gorender já participava da importante publicação. O jovem estudante da Faculdade de Direito homenageava Castro Alves em tal revista, identificando nele as qualidades afinadas com a experiência de enfrentamento ao fascismo então corrente:

\begin{abstract}
Ele é um dos nossos. É um dos milhões de jovens que se levantaram e empunharam as armas para defender o legado espiritual da dignidade humana. É um dos milhões de combatentes que, no mundo inteiro, se entregam ao sacrifício pela sobrevivência de liberdades conquistadas com tanto sangue. De todos os soldados em armas contra o fascismo, é ele o mais exaltado, o mais heroico e o mais clarividente. É aquele que nos conduz aos frêmitos do perigo, aquele que nos ensina a serena permanência nos postos de combate, aquele que envia, em sons multiplicados, a nossa decidida resposta aos trânsfugas e aos falsos profetas. Ele é Castro Alves. O maior cantor do continente americano está conosco. Sentimos, em todos os setores da luta, a sua viva presença. Através de todos os combates em que nos empenhamos, estamos sempre a divisar o seu vulto de gigante invicto. [...] Nesse momento decisivo da nossa história, sua presença imortal está na aclamação das ruas, no clamor das multidões, no entusiasmo dos jovens. E nesta hora de profundas transformações, Castro Alves não é um vulto do passado e sim um vanguardeiro do futuro. ${ }^{63}$
\end{abstract}

A contribuição mais importante do novato à Seiva, porém, se deu meses depois dessa apropriação antifascista da figura de Castro Alves. Data de 20 de junho de 1943 a chegada do general Manoel Rabelo em solo baiano, tendo em vista a instalação de um núcleo local da Sociedade Amigos da América, polo que agregou

60 GORENDER apud FALCÓN. Do reformismo à luta armada, p.83.

61 FALCÃO. O Partido Comunista que eu conheci, p.48.

62 SENA JÚNIOR. Os impasses da estratégia, p.82.

63 GORENDER, Jacob. Castro Alves - Guia dos combatentes da liberdade. IN: Revista Seiva. Ano III, n.14, outubro de 1942, sessão "História, arte e literatura”. BPEB. Setor: Periódicos Raros, Acervo: Jornais. p.38-39. 
em vários espaços aqueles interessados no ingresso brasileiro na frente de batalha inimiga do Eixo. ${ }^{64}$ Ocasião e presença celebradas que renderam uma entrevista publicada no número de julho de Seiva. Conduzida pelo jovem repórter e secretário da revista, Jacob Gorender, logrou divulgação em importantes veículos do centro brasileiro, com declarações contundentes de Rabelo, tais como: "Os soldados devem ser treinados para a guerra e não empregados em serviços inúteis"; "Ao Corpo Expedicionário não poderá caber o papel de “cavalheiros de Offenbach"; "Hitler tira partido do temor do comunismo". 65

Primeira crítica séria à forma com que o governo varguista conduzia sua política militar a ser publicada na imprensa brasileira, a entrevista com o general rendeu à Seiva o seu fechamento e a prisão de diretores e redatores: "Assim é que João Falcão, Wilson Falcão e Jacob Gorender foram detidos, no dia 15 de julho, e levados para a Guarda Civil, ao mesmo tempo em que eram denunciados ao Tribunal de Segurança Nacional como subversivos". ${ }^{66}$ Como não cabia prender um membro do alto oficialato nacional, a culpa pela vexatória acusação caiu em cima dos jovens, acusados de publicarem uma entrevista apócrifa.

Essa foi a primeira prisão de Gorender. O cárcere era um risco a que os comunistas e opositores em geral eram constantemente submetidos. Falcão relembra de uma sensação de revolta que abateu sobre si (e provavelmente também em seus colegas de aprisionamento) por causa da nota emitida pelo Comandante da VI Região Militar, na qual os três detidos são acusados como "ofensores da dignidade do Exército". Mesmo em condições adversas, não tardaram em responder à acusação:

Acontece que Jacob Gorender havia submetido ao general, antes da impressão, o texto da entrevista que foi por ele aprovado. Eu redigi, então, com a colaboração de Jacob e Wilson um pequeno mas enérgico manifesto ao povo baiano com o título "Quem ofende a dignidade do Exército", e consegui que ele chegasse ao Comitê Regional do Partido, para mimeografá-lo e distribuí-lo clandestinamente. Em resumo, eu rebatia com veemência as acusações acima e dizia que nós, jovens antifascistas, que vínhamos há muitos anos lutando pela liberdade e independência de nossa pátria e contra o nazifascismo, e estávamos aguardando a nossa hora de ir lutar nos campos da Europa ou África, éramos os verdadeiros patriotas, e que quem ofendia o Exército eram aqueles que, fazendo o jogo da quinta coluna, retardavam o envio da Força Expedicionária Brasileira e maltratavam os nossos jovens irmãos, convocados para a guerra e não para fazer faxina nos quartéis. ${ }^{67}$

O ato arbitrário repercutiu largamente. Mobilizaram-se pela soltura dos jovens envolvidos no VI Congresso Nacional de Estudantes, ocorrido no Rio de Janeiro. Esses contataram o general Manoel Rabelo para a confirmação de sua entrevista, que assumiu responsabilidade pelos ditos e reforçou as denúncias que antes fizera. Em audiência com o presidente Getúlio Vargas, conseguiram tanto a soltura quanto a suspensão da denúncia ao Tribunal de Segurança. ${ }^{68}$

A manifestação de um destacado militar foi um impeditivo aos desmandos na prisão e provável processo que enfrentariam os Falcão e Gorender. Impulsionou

64 SENA JÚNIOR. Os impasses da estratégia, p.149.

65 FALCÃO. O Brasil e a Segunda Guerra Mundial, p.184.

66 FALCÃO. O Brasil e a Segunda Guerra Mundial, p.186.

67 FALCÃO. O Brasil e a Segunda Guerra Mundial, p.249.

68 FALCÃO. O Brasil e a Segunda Guerra Mundial, p.186. 
também as mobilizações populares aglutinadas em torno da questão bélica. Os comunistas, porém, não puderam comemorar de todo: graças ao incidente, a revista Seiva teve proibida a sua circulação, sendo derradeira a edição número 18, de julho de 1943.

Concomitante aos variados apelos pela entrada brasileira na guerra em curso na Europa havia as disputas internas do PCB. Unido em apoio aos aliados, encontrava-se, porém, fraturado pelos anos de repressão e principalmente pelas divergências com relação ao Estado Novo. Os comunistas baianos e cariocas marcam posição pela União Nacional, já mencionada anteriormente, agora não apenas contra o inimigo do Eixo, mas também em apoio ao governo brasileiro de Vargas. ${ }^{69}$

Em agosto de 1943, militantes se reúnem no Vale do Paraíba para a II Conferência Nacional do PCB, também conhecida como Conferência da Mantiqueira. Ali foi ratificada a União Nacional interna e externa, a qual implicou em pioneirismo dos comunistas nas reivindicações de participação militar do Brasil no front. Consequência organizativa importante do encontro foi a formação de um novo Comitê Central Provisório, a Comissão Nacional de Organização Provisória (CNOP). Dentre os novos dirigentes do partido encontram-se Diógenes Arruda e Mário Alves, o estudante que recrutou Jacob Gorender. ${ }^{70} \mathrm{~A}$ ação se intensificava para os comunistas, os esforços não deveriam ser medidos frente à ameaça nazifascista. Gorender mesmo já fora vítima de prisão por simplesmente se opor às forças do Estado Novo. Novos rumos e demandas, de caráter político e organizativo, se abriam aos comunistas.

Recebido em 27/07/2016

Aprovado em 08/12/2016 